\title{
The GCC States and the Shifting Balance of Global Power
}

Kristian Coates Ulrichsen

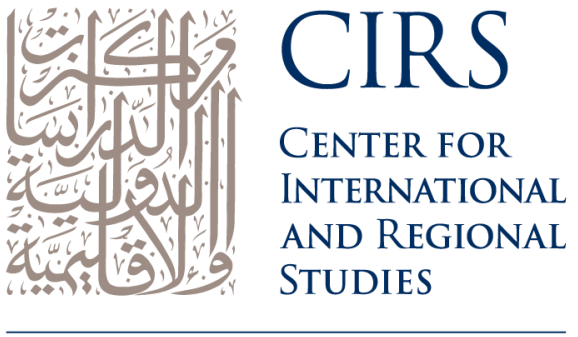

GEORGETOWN UNIVERSITY SCHOOL OF FOREIGN SERVICE IN QATAR 


\section{The GCC States and the Shifting Balance of Global Power}

Kristian Coates Ulrichsen

(C) 2010 Center for International and Regional Studies

Georgetown University School of Foreign Service in Qatar

Occasional Paper No. 6

ISSN 2072-5957 


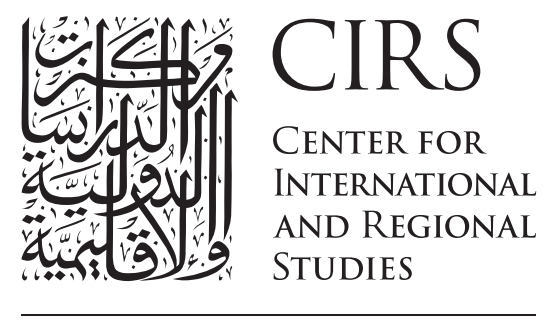

GEORGETOWN UNIVERSITY

SCHOOL OF FOREIGN SERVICE IN QATAR

Established in 2005, the Center for International and Regional Studies at the Georgetown University School of Foreign Service in Qatar is a premier research institute devoted to the academic study of regional and international issues through dialogue and exchange of ideas, research and scholarship, and engagement with national and international scholars, opinion makers, practitioners, and activists.

Guided by the principles of academic excellence, forward vision, and community engagement, the Center's mission revolves around five principal goals:

- To provide a forum for scholarship and research on international and regional affairs

- To encourage in-depth examination and exchange of ideas

- To foster thoughtful dialogue among students, scholars and practitioners of international affairs

- To facilitate the free flow of ideas and knowledge through publishing the products of its research, sponsoring conferences and seminars, and holding workshops designed to explore the complexities of the twenty-first century

- To engage in outreach activities with a wide range of local, regional and international partners.

This publication series is made possible by the generous support of Qatar Foundation for Education, Science and Community Development. 


\section{The GCC States and the Shifting Balance of Global Power}

Kristian Coates Ulrichsen

Kristian Ulrichsen is a Research Fellow on the Kuwait Research Programme on Development, Governance and Globalisation in the Gulf States at the London School of Economics and Political Science. His forthcoming books include Insecure Gulf: The End of Certainty and the Transition to the Post-Oil Era and The Transformation of the Gulf: Politics, Economics and the Global Order (co-edited with David Held). 



\begin{abstract}
This paper maps the changing engagement strategies of the six member-states of the Gulf Cooperation Council in the global order. It examines how and why the Gulf states have emerged as visible and powerful global actors in recent years and contextualizes these strategies within the shifting balance of global power. This approach ascribes agency to policymakers in the Gulf states, and shifts the focus of scholarly attention toward the motivations and objectives that guide their engagement and interaction with the international system. The paper also considers the broader implications for the future of global and regional politics in light of the emergence of new international linkages and blocs, and the reformulation of frameworks of global governance in both its normative and structural dimensions.
\end{abstract}

\title{
Introduction
}

The states of the Gulf Cooperation Council (GCC) have emerged as powerful international actors in the first decade of the twenty-first century. ${ }^{1}$ Led by Saudi Arabia, Qatar, and the United Arab Emirates (UAE), they have visibly deepened their involvement in global issues, ranging from energy governance, to the politics of climate change, and reforms to the global financial architecture. This is occurring within a rapidly globalizing and increasingly multi-polar system in which power is more diffuse and increasingly refracted through overlapping layers of national, regional, and global governance. At its heart lies a global rebalancing of geopolitical and geo-economic power from West to East centering around the pivotal commercial and strategic position of the oil-rich monarchies of the Arabian Peninsula.

These interlinked processes have profound implications for the intra-regional and international relations of the Gulf,and are creating complex newinterdependencies that bind the Gulf states to global structures and provide the parameters for their engagement within the international community. Simultaneously, the Gulf states' greater willingness to take proactive steps in reshaping the institutional design of global frameworks of governance have produced nuanced and multi-dimensional strategies designed to manage the impact of the processes of globalization. This has resulted in greater visibility and voice in existing international organizations as well as the new institutional architecture emerging out of the global financial and economic crisis of 2007-2010.

This article refers to the six member-states of the Gulf Cooperation Council as the Gulf States: Bahrain, Kuwait, Oman, Qatar, Saudi Arabia and the United Arab Emirates. 
This paper begins by mapping the changing engagement strategies of the Gulf states in the changing global order. This leads to a second section that explores the motivations and objectives that guide regional decision-makers in their engagement at the global level and is followed by a third section that examines the mechanisms through which these are operationalized. A fourth section contextualizes these trends within the broader processes of globalization and the creation of a global politics, while a fifth and concluding section addresses the implications for global and regional layers of governance in both their normative and structural dimensions. The central question throughout is an analysis of what motivates policymakers in their engagement in global issues and how this is tied to the repositioning of the Gulf in the changing balance of global power. The paper adds comparative analytical value to existing globalization literature and to the growing body of research that examines global governance, both as a normative (Western-centric) concept and from the practical perspective of non-Western approaches to the governance of globalization.

\section{Mapping the Changing Engagement Strategies of the Gulf in the Global Order}

Profound structural changes in the global economic order and patterns of trade have opened up tremendous new opportunities for the Gulf states since the turn of the millennium. The region is internationalizing rapidly and emerging as the center of gravity in West Asia by virtue of its hydrocarbon reserves and financial resources. A milestone was reached in 2009 when Saudi Arabian oil exports to China exceeded for the first time those to the United States, as surging Chinese demand intersected with a $50 \%$ drop in American requirements during the financial and economic downturn. ${ }^{2}$ Issues of energy interdependence, concerns for maritime security and, since 2007 , food security delineate the parameters of this expansion of political and economic links between Eurasian powers and the Gulf states. ${ }^{3}$ Their interplay has simultaneously deepened existing ties and created new strategic and commercial linkages in sustainable long-term partnerships. ${ }^{4}$ Together these thickening relations are transforming the nature of Gulf-Asia ties and reformulating regional dynamics in subtle yet important ways. ${ }^{5}$

At a macro-level the broad contours of this multi-dimensional shift are already taking shape. In 2001, China's tenth Five-Year Plan (2001-2005) explicitly referred to the concept of energy security for the first time, and in 2005 it opened a deepwater

${ }^{2}$ Jad Mouawad, "China's Growth Shifts the Geopolitics of Oil," The New York Times, March 19, 2010.

3 Samir Ranjan Pradhan, "GCC-Asia Relations: Intensifying Cooperation Beyond Mutual Interdependence," in Gulf Yearbook 2008-2009, ed. Abdulaziz Sager (Dubai: Gulf Research Centre, 2009), 165.

${ }^{4}$ Ramesh Mathew, "Indian PM Woos Qatar Investment," Gulf Times, November 11, 2008.

5 Steve A. Yetiv and Chunlong Lu, "China, Global Energy and the Middle East," Middle East Journal 61, no. 2 (2007): 165 . 
seaport and naval base at Gwadar, in Pakistan. Its location near the mouth of the Strait of Hormuz gives China a degree of strategic depth in the Arabian Sea in addition to a transit terminal for crude oil imports from the Middle East and Africa. ${ }^{6}$ Its emerging blue-water capabilities took another step forward in March 2010 when two Chinese warships docked in Abu Dhabi's Port Zayed following their completion of a six-month mission combating maritime piracy in the Gulf of Aden. Their visit marked the first-ever Chinese naval visit to the Gulf. During the occasion, China's ambassador to the UAE Gao Yu Sheng affirmed his country's interest in regional stability as he stated, "Maintaining security in the Gulf is vital to the area and the world, including China."

India too views the Gulf as an intrinsic part of its broader strategic and commercial neighborhood. Following an extended period of frigidity in Indian-Gulf relations in the 1970s and 1980s, India's re-emergence in the Gulf gathered pace in the 2000s. Indian Prime Minister Manmohan Singh visited the region in November 2008 and signed defense cooperation agreements with Qatar and Oman on maritime security, data-sharing, and common threat perceptions, and, in February 2010, upgraded India's bilateral relationship with Saudi Arabia to a Strategic Partnership. ${ }^{8}$ The GCC states already meet 70\% of Indian energy requirements and host more than 4.5 million Indian laborers. The Indian Vice President Shri Mohammed Hamid Ansari reaffirmed in April 2009 that these multidimensional ties were based on "the fundamental premise that the region is part of our natural area of economic interaction." Russia also has significantly expanded its political and economic links to the Gulf in general, and to its fellow oil and gas-producers Qatar and Saudi Arabia in particular. Then president Vladimir Putin's visit to the Gulf in February 2007 was the first ever by a Soviet or post-Soviet leader, and it conveyed part of a broader Russian intention to increase its role in the Middle East and become one of the key actors in any new regional security system. ${ }^{10}$

Ties of energy interdependence with the Asian giants form the central pillar of the Gulf states' eastward orientation. Global energy flows are undergoing a fundamental shift in the pattern of consumption as the enormous demand for imported oil from China and India competes with traditional markets in the Western industrialized countries. In 2008, the International Energy Agency's World Energy Outlook estimated that China would account for 43\% and India for 19\%

${ }^{6}$ Ibid., 199.

7 Mahmoud Habboush, "Chinese Warships Make First Visit to Port Zayed," The National, March 24, 2010.

8 Ramesh Mathew, "Qatar and India Agree to Expand Security Ties," Gulf Times, November 10, 2008; Personal interview, London, May 2010.

9 Sajeev K. Peter, “Kuwait, India Sign Three Agreements," Kuwait Times, April 8, 2009.

${ }^{10}$ Mark A. Smith, "Russia and the Persian Gulf: The Deepening of Moscow's Middle East Policy," (Middle East Series Paper, Conflict Studies Research Centre, Defence Academy of the United Kingdom, 2007), 5. 
of the increase in global oil demand through 2030. ${ }^{11}$ Although the global economic downturn will have tempered the growth in demand, the general direction of future patterns is clear. Again, IEA estimates forecast that China's share of imported oil will double from $40 \%$ to $80 \%$ of its total oil needs by 2030 , an increase in absolute terms from below 2 million barrels per day in 2002 to 11 million barrels per day, with more than half of this coming from Gulf producers. ${ }^{12}$ Similar patterns of accelerating interdependencies also characterize the flow of oil and natural gas from the Gulf to South Korea, Japan, and other East Asian states. ${ }^{13}$

Although the GCC-European relationship remains integral to both sides, and all six Gulf states remain reliant on the external security guarantee provided by the United States, recent developments demonstrate how the Gulf is repositioning itself between West and East. ${ }^{14}$ Notably, Saudi Arabia responded to the $7 \%$ cuts in oil production agreed at the December 2008 OPEC meeting by concentrating the curbs in supply on European and North American customers to the benefit of Asian refineries. ${ }^{15}$ Meanwhile, Qatar Petroleum and the China National Offshore Oil Company (CNOOC) concluded a range of deals in 2008-2009, including a twentyfive year Exploration and Production Sharing Agreement that will make Qatar the largest supplier of liquefied natural gas to China. These agreements underscored the two countries' geo-strategic interdependence and prompted CNOOC president $\mathrm{Fu}$ Cheng Yu to comment, that "the global economy is in fundamental reshaping and we have determined to build up strategic partnership in the energy field with Qatar." ${ }^{\text {. }}$ The Emir of Qatar Sheikh Hamad bin Khalifa Al-Thani voiced similar thoughts in March 2009 as he stated that "China is coming, India is coming and Russia is on its way [...] I think they will recover. I don't know if America and Europe will still be leading." ${ }^{17}$

Deepening Gulf-Asia ties represent an important element of the GCC states' ambitious projects of economic diversification. Both Saudi Aramco and the Kuwait Petroleum Corporation entered into landmark agreements with the China Petroleum and Chemicals Group (Sinopec) to participate in joint venture integrated refinery and petrochemical complexes in Fujian and Guangdong provinces that will

${ }_{11}$ Andreas Goldthau and Jan Martin Witte, "Back to the Future or Forward to the Past? Strengthening Markets and Rules for Effective Global Energy Governance," International Affairs 85, no. 2 (2009): 381.

12 Mahmoud Ghafouri, “China's Policy in the Persian Gulf," Middle East Policy 16, no. 2 (2009): 82.

13 Christopher M. Davidson, "Persian Gulf - Pacific Asia Linkages in the 21 ${ }^{\text {st }}$ Century: A Marriage of Convenience?" (Working Paper 7, Kuwait Programme on Development, Governance, and Globalisation, London School of Economics, 2010), 11, 14.

14 Abdullah Baabood and Geoffrey Edwards, "Reinforcing Ambivalence: The Interaction of Gulf States and the European Union," European Foreign Affairs Review 12, no. 4 (2007): 546-47.

15 "Saudi to Keep June Oil Supply Steady to Asia," Reuters, May 12, 2009.

16 "Qatar to Become Largest LNG Supplier to China," The Peninsula, September 2, 2009.

17 "Qaatari Emir Warns of Another Iraq if Sudan Sinks into Chaos," Gulf Times, March 31, 2009. 
process crude oil supplied by the two Gulf states. ${ }^{18}$ In terms of food security too, emerging partnerships are creating durable new linkages between the GCC states and agricultural countries in Africa and Asia, spurred on by the high food-price inflation in 2007-2008 and the demographic and ecological imperatives of rapidlyrising populations and decreasing water tables. ${ }^{19}$ In order to mitigate and pre-empt any potential social unrest caused by high dependence on imported foodstuffs, all of the GCC states have made moves to increase their own food production by outsourcing to food-producing states in Asia and Africa. ${ }^{20}$

Saudi officials created an investment fund in 2008 specifically to purchase agricultural land in Pakistan to meet domestic demands for rice and wheat, and other agreements or negotiations are underway between Bahrain and Pakistan, Qatar and Sudan, the UAE and Sudan, and the UAE and Kazakhstan. ${ }^{21}$ The importance of food and energy security issues in drawing together the GCC states with the Association of Southeast Asian Nations (ASEAN) was publicly affirmed during the two blocs' first joint meeting of foreign ministers in June 2009. Officials disclosed plans to move toward building a trade bloc based on food and oil that would secure ASEAN states' energy security while meeting GCC states' food security, as ASEAN General Secretary Suring Pitsuan noted presciently, "You have what we don't have, and we have in plenty of what you don't have, so we need each other."22

This economic realignment notwithstanding, all of the GCC states remain firmly integrated into bilateral security arrangements with Western powers, notably the United States. With the redeployment of US combat troops in Iraq, and the ongoing dispute between Iran and the international community, these ties are unlikely to decrease in the foreseeable future. Work has already started on a $\$ 580$ million upgrade to the US Fifth Fleet Command's naval base in Bahrain, which is set to double in size by $2012 .{ }^{23}$ Other developments, such as the opening of the first French naval base in the Gulf (in Abu Dhabi) in May 2009, underline the continuing importance of the region to Western geo-security and commercial interests. ${ }^{24}$ Neither China nor India currently possesses the capability or intent to add a security dimension to their strengthening relationships with the GCC states. Consequently, the task facing policymakers in the Gulf states is how to best balance

\footnotetext{
18 "Kuwait and China Sign Energy, Other Pacts," Saudi Gazette, May 11, 2009; Wan Zhihong, "Sinopec's Fujian Plant up, Running," China Daily, November 12, 2009.

19 Alan Dupont and Mark Thirlwell, "A New Era of Food Insecurity?," Survival 51, no. 3 (2009): 88.

${ }^{20}$ Eckart Woertz, "The Gulf Economies in 2008," in Gulf Yearbook 2008-2009, ed. Abdulaziz Sager (Dubai: Gulf Research Centre, 2009), 239.

21 "Saudis Setting up Fund to Buy Agricultural Land Abroad," GulfTimes, August 26, 2008; Personal interview, Dubai, October 2009.

22 "Gulf States and ASEAN Eye New Trade Bloc Based on Food, Oil," The Peninsula, July 1, 2009.

23 Mazen Mahdi, "US to Double Size of Bahrain Naval Base," The National, May 27, 2010.

${ }^{24}$ Edward Cody, "First French Military Base Opens in the Persian Gulf," The Washington Post, May 27, 2009.
} 
their ongoing western defense and security orientation with the shifting eastward focus on trade links and geopolitical cooperation with other emerging world-powers.

\section{Motivations and Objectives of Gulf Policymakers}

Having mapped the broad outlines of the Gulf states' repositioning within the international system, this second section concentrates on the motivations and objectives that guide regional policymakers. It thus ascribes agency to local actors as they navigate the changing structure of the international system and proactively shape it to their advantage. Analytically, it follows the theoretical framework developed by Gerd Nonneman arguing that the Arab Gulf monarchies engage globally in order to boost their position domestically and regionally. ${ }^{25}$ This approach emphasizes the myriad cross-cutting obstacles to regional and global governance amid the continuing relevance of state-centric approaches as the dominant frame of reference in the GCC states. ${ }^{26}$

The interaction of two macro-factors contextualizes the environment within which regional policymakers acted. The first is the revenues that accrued to GCC states during the 2002-2008 oil boom and the policy decisions on how to deploy them, while the second is the systemic flaws in the western-led Washington Consensus of economic development that became fully apparent in the global financial and economic crisis beginning in $2007 .{ }^{27}$ Taken together, they have greatly enhanced the profile and positioning of GCC states within the international system, as they emerged as actors with powerful leverage in the debate over reshaping the institutional architecture of global governance. This has been reflected in Gulf policymakers' increasing confidence in the international arena and greater awareness of their pivotal position within the global rebalancing of economic and political power. $^{28}$

Implicit in this projection of a greater regional voice is a determination to shape the emerging regulatory structures and thereby maximize their own objectives and interests. This is consistent with GCC ruling families' track record of pursuing pragmatic strategies of survival, designed to manage the transformational shifts in their domestic and international circumstances in recent decades. ${ }^{29}$ In May 2009, the Qatari Prime Minister and Minister of Foreign Affairs, Sheikh Hamad bin Jasim bin

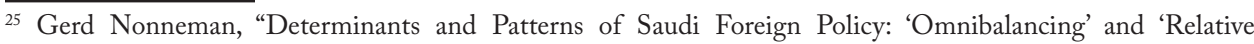
Autonomy' in Multiple Environments," in Saudi Arabia in the Balance: Political Economy, Society, Foreign Affairs, ed. Paul Aarts and Gerd Nonneman (London: Hurst, 2005), 316.

${ }^{26}$ Abdullah Baabood, "Dynamics and Determinants of the GCC States' Foreign Policy, with Special Reference to the EU," in Analyzing Middle Eastern Foreign Policies, ed. Gerd Nonneman (London: Routledge, 2005), 148.

${ }^{27}$ David Held, "Multilateralism and Global Governance: Accountability and Effectiveness," in Progressive Foreign Policy: New Directions for the UK, ed. David Held and D. Mepham (Cambridge: Polity Press, 2007), 207.

${ }_{28}$ Personal interviews, Kuwait, Abu Dhabi and Dubai, October 2009.

${ }^{29}$ Joseph Kostiner, Middle East Monarchies: The Challenge of Modernity (Boulder: Lynne Rienner, 2000), 8. 
Jabr Al-Thani, addressed the broader objectives that motivated Qatari policymakers in the processes of global restructuring. He called for a profound reshaping of the organizational frameworks in the dominant political system to reflect the emergence of a multi-polar order in which the West was no longer the sole player in world affairs. $^{30}$

Building on this, and taking advantage of its position in the G20 and on the board of the International Monetary Fund, Saudi officials in particular have been positioning the kingdom to play a vital role in the debates over reshaping the global financial architecture. ${ }^{31}$ This reflects the Gulf states' greater confidence and enhanced willingness to project their increased financial influence on to the global stage. Cumulatively, the GCC states accrued $\$ 912$ billion of foreign assets during the five years preceding June 2008, and their sovereign wealth funds played a visibly significant role in providing liquidity to struggling Western financial institutions during the initial phase of the financial crisis in 2007 and early-2008. ${ }^{32}$ Gulf policymakers nevertheless remain acutely sensitive to any possible legal or political backlash to greater levels of Gulf investment in the West, and the United States in particular. They are also anxious to avoid any repeat of the humiliation suffered by the UAE during the Dubai Ports World affair in 2006 when the group acquired a ports management contract in the US, attracting a great deal of negative press. ${ }^{33}$ Keen to pre-empt any potential future misunderstandings or entanglement in a similar controversy, one Gulf Ambassador requested the US government to produce a list of "strategic sectors" that investors should avoid. Notably, however, they were unable to do so. ${ }^{34}$

Ruling officials in Qatar and the UAE have spearheaded a complementary approach designed to maximize their visibility in the international arena by carving out niches in which they can become world leaders in specialized fields. ${ }^{35}$ Qatar has cultivated a growing international reputation for diplomacy mediation in areas as diverse as Darfur, the Philippines, and Lebanon, where it brokered a landmark peace agreement in 2008. ${ }^{36}$ Within the United Arab Emirates, Abu Dhabi has sought to project itself as a leader in renewable energy research and governance through its flagship Masdar Initiative and headquartering of the International Renewable Energy

\footnotetext{
${ }^{30}$ Ourouba Hussein, “Qatari PM Stresses Rule of Law to Face Challenges," Gulf Times, May 31, 2009.

31 Abdulaziz O. Sager, “The G20 Meeting and Gulf Interests,” Gulf Research Centre, accessed October 10, 2010, http://www.grc.ae.

32 Samba Financial Group, "Tracking GCC Foreign Investments: How the Strategies are Changing with Markets in Turmoil," (Samba Report Series, Samba Financial Group, Riyadh, December 2008), 6; Sven Behrendt, "Beyond Santiago: Status and Prospects," Central Banking 19, no. 4 (2009): 76.

33 Personal interviews, Kuwait, Bahrain and Dubai, October 2009.

34 Personal interview, Washington DC, January 2009.

35 Personal interview, Cambridge, September 2009.

36 Robert F. Worth, “Qatar, Playing All Sides, Is a Non-Stop Mediator," The New York Times, July 9, 2008.
} 
Agency. ${ }^{37}$ Neighboring Dubai also caught the world's attention with its seemingly unbounded "Dubai model" of economic diversification and succession of spectacular mega-projects, before its ignominious implosion in 2008-2009..$^{38}$ Meanwhile, all three, along with Saudi Arabia, have invested heavily in world-class research and development facilities in the social and natural sciences and have collaborated with leading Western academic institutions to create educational hubs, such as Education City in Qatar and the $\$ 10$ billion-endowed King Abdullah University of Science and Technology in Saudi Arabia. ${ }^{39}$

Policymakers in the Gulf states thus view global engagement as a pillar crucial to their domestic and regional posture. Furthermore, their polities are simultaneously becoming more enmeshed in existing layers of global governance through membership of institutions such as the World Trade Organization, which Saudi Arabia finally joined in December 2005 following twelve years of accession talks. ${ }^{40}$ Membership in these organizations is significant as it benchmarks domestic governance to international standards, while participation in an international rules-based system introduces a new dynamic to domestic reform processes. It also enhances regional familiarity with global values and helps to embed them in local discourses while situating Gulf states' views of global governance within a broader non-Western paradigm shared by many developing countries, including India and China.

\section{The Mechanisms of Change}

This section explores the ways in which the GCC states are actively transforming their position and role within the international system. It focuses on three major policy areas - the global financial architecture, the emerging frameworks of energy governance, and the politics of climate change - to demonstrate how Gulf policymakers'actions fit into the broader rebalancing of global power. Operationalizing these instances of interaction with existing layers of global governance provides a valuable new dimension to studies of the ongoing reformulation of global structures of governance, as well as to the incipient and informal networks and coalitions being constructed to achieve this.

With the global economy in a state of flux following the 2008 crash, the GCC states seized the opportunity to project their interests in the debate over the reshaping of the global financial architecture. This is particularly the case for

\footnotetext{
37 “Abu Dhabi Home for World Energy Body," The Peninsula, June 30, 2009.

38 Martin Hvidt, “The Dubai Model: An Outline of Key Development-Process Elements in Dubai," International Journal of Middle East Studies 41, no. 3 (2009): 400.

39 Vincent Romani, "The Politics of Higher Education in the Middle East: Problems and Prospects," (Middle East Brief 36, Crown Center for Middle East Studies, Brandeis University, 2009), 4.

40 Rodney Wilson, "Economic Governance and Reform in Saudi Arabia," in Reform in the Middle East Oil Monarchies, ed. Anoushiravan Ehteshami and Steven M. Wright (Reading: Ithaca Press, 2008), 137.
} 
Saudi Arabia by virtue of its position on the G20, but also for the UAE, Qatar, and Kuwait which possess sizeable sovereign wealth funds that allow them a degree of global reach. Policymakers in the Gulf initially expressed their "surprise" that they were being asked to bail out a crisis that appeared to them to have originated in the United States. ${ }^{41}$ It was in this context that Saudi officials interpreted the then British Prime Minister Gordon Brown's visit to the Gulf ahead of the G20 meeting in November 2008. Thus, Finance Minister Ibrahim Abdulaziz Al-Assaf rebuffed Brown's proposal that the GCC states spend "hundreds of billions" of dollars on an IMF rescue package for emerging markets by replying pointedly that "We have been playing our role responsibly and we will continue to play our role, but we are not going to finance the institutions just because we have large reserves." ${ }^{42}$

Early hopes that the GCC states might decouple themselves from the global financial crisis evaporated in the face of plunging oil prices, the drying up of project financing, and the bursting of the real estate speculative bubble in the second half of $2008 .{ }^{43}$ This was followed in 2009 by the internationalization of corporate and financial crises in Saudi Arabia and Dubai, which affected local, regional, and international institutions alike, and revealed major deficiencies in corporate governance and financial disclosure. ${ }^{44}$ The powerful demonstration of the transnational linkages that bound Gulf economies inextricably to broader global processes also made clear the Gulf's stake in shaping the global response and recovery measures. As such, Gulf responses to the financial and economic crisis in 2008 were, for the most part, responsible and measured, with Saudi Arabia gaining international praise for its role in stabilizing world oil markets. In fact, US Secretary of the Treasury Timothy Geithner publicly praised "the scale of ambition and investment we are seeing in the kingdom and the Gulf region to lay the foundation for future growth." ${ }^{45}$

It is in this vein that Saudi officials have exhibited a willingness to participate in developing-country moves to reshape the architecture of international financial institutions. Al-Assaf has joined with other emerging powers such as Brazil, Russia, India, and China to push for increasing the voting powers of developing countries in the IMF at the expense of "overrepresented" developed states. ${ }^{46}$ During a visit to Saudi Arabia in February 2009, Chinese President Hu Jintao pledged to work with the GCC "with a view to reforming the global financial institutions." ${ }^{\text {"7 }}$ This reflects the urgency ascribed by all major emerging, non-Western economies to reformulate

\footnotetext{
41 "Gordon Brown in the Gulf to Seek World Bailout Support," Khaleej Times, October 30, 2008.

42 "Saudi Arabia Not Mulling More Cash for IMF: Minister," Reuters, November 16, 2008.

43 Woertz, "Gulf Economies in 2008," 233.

44 "Riyadh is the Gulf's New Financial Centre," Middle East Economic Digest, June 26, 2009; Kristian Ulrichsen,

"Dubai's Downfall Exposes the Political Ties that Bind in a Tangled Web," Daily Telegraph, December 2, 2009.

45 "US Praises Gulf Investments to Push Growth," Agence France-Presse, July 14, 2009.

46 "Saudi Says IMF Reforms Should Not Be at Its Expense," The Peninsula, September 5, 2009.

47 Ghanzafar Ali Khan, "China to Boost Relations with GCC: President Hu," Arab News, February 12, 2009.
} 
the nature of these institutions, as well as their role and voice within them, although the rebalancing of national and regional quotas and voting rights in the IMF remains notably contested and potentially divisive in the long-term. ${ }^{48}$

One area in which the Gulf states can project greater leverage is in reshaping global attitudes toward sovereign wealth investment. The rapid rise of sovereign wealth funds in the 2000s introduced into the realm of global monetary governance a powerful new dynamic regarding relations between, and the differing priorities of, home governments and recipient countries. ${ }^{49}$ The importance of sovereign wealth funds became fully apparent in the aftermath of the global financial crash as European governments, led by the United Kingdom, actively sought Gulf support for the injection of short-term liquidity into European markets, while the outgoing Bush administration reportedly sought $\$ 300$ billion from Saudi Arabia, the UAE, Kuwait, and Qatar to bail out the US automobile industry. ${ }^{50}$ During the autumn of 2008, Gulf sovereign wealth funds accounted for approximately one-third of the emergency funding that European governments made available, before diverting liquidity into propping up ailing domestic markets and financial institutions. ${ }^{51}$

Nevertheless, the eagerness with which Gulf investment was pursued contrasted sharply with the attitude of distrust that greeted previous sovereign wealth investments in the West. Two episodes in particular - the Kuwait Investment Authority's attempted purchase of a substantial stake of British Petroleum in 1988 and Dubai Ports World's acquisition of a ports management contract in the United States in 2005-2006 - greatly harmed Gulf perceptions of a level playing field in Western financial markets. One senior official at a major Kuwaiti bank summed up the lingering feelings of bitterness toward perceived Western "hypocrisy" by stating that "they need the money and then they politicize it. Perhaps they think we are all bin Laden. Either they want the money or not." ${ }^{2}$ Other officials in the Gulf express dissatisfaction at the failure of Western officials to adequately respond to requests either to define "strategic industries" or to indicate which sectors Gulf investors should refrain from moving into..$^{33}$

The challenge facing both Gulf states and recipient countries is integrating the governance of sovereign wealth funds in a manner that addresses the different priorities and concerns of both groups. The Generally Accepted Principles and Practices (also known as the Santiago Principles) published in October 2008, and

\footnotetext{
${ }^{48}$ Sager, "The G-20 Meeting;" "Saudi Says IMF Reforms Should Not Be at Its Expense."

${ }^{49}$ Benjamin J. Cohen, "Sovereign Wealth Funds and National Security: The Great Tradeoff," International Affairs 85, no. 4 (2009): 713.

50 “US Seeks \$300bn from Gulf States to Tackle Turmoil," Agence France-Presse, November 21, 2008.

${ }^{51}$ Richard Youngs, "Impasse in Euro-Gulf Relations," (Working Paper 80, Fundación para las Relaciones Internacionales y el Diálogo Exterior, Madrid, 2009), 2.

52 Personal interview, Kuwait, October 2009.

${ }^{53}$ Personal interviews, Bahrain, Kuwait and Dubai, October 2009.
} 
the Kuwait Declaration of April 2009, set out a voluntary code of conduct that one Gulf analyst labeled an "innovative approach to global governance" as it sought to integrate industrialized and emerging countries in a collective framework. ${ }^{54}$ However, the principles remain voluntary and issues of non-transparency and poor accountability continue to present formidable challenges to incipient frameworks of governance.$^{55}$ For their part, the industrialized OECD countries have yet to formulate regulatory proposals that satisfactorily address sovereign investor countries' unease at the ambiguity and vagueness of the definition of "national security" sectors. ${ }^{56}$

Although there is still a considerable way to go toward a comprehensive governing framework, it is nonetheless significant that the GCC states (led by the Abu Dhabi Investment Authority) have taken proactive steps to identify and address some of the core challenges to the governance of sovereign wealth funds. Implicit in this projection of a greater regional voice is a determination to shape the emerging regulatory structures and thereby maximize their own objectives and interests. This is indicative of the Gulf states' increasing confidence in the international arena and greater awareness of their pivotal position within the global rebalancing of economic and political power. ${ }^{57}$ It is consistent with the ruling regimes' highly developed instincts for survival as they negotiate the changing international political economy and maximize their own stake within the new global order emerging from the systemic crises in both the Washington Consensus and the post-September 11 security doctrine. ${ }^{58}$

A broadly similar dynamic animates Gulf states' engagement in global energy governance and the politics of climate change. State-led efforts to brand themselves as world leaders in renewable and alternative energy research stand in direct contradistinction to their environmentally unsustainable development policies and their obstructionist positions in climate change negotiations. ${ }^{59}$ The national and regional political economy of rent redistribution and energy-intensive economic diversification in the Arabian Peninsula mean that, individually and collectively, the GCC states have a considerable stake in shaping global discussion and decisionmaking processes. There is thus considerable tension at the heart of regional attempts to portray the Gulf states as responsible actors in global energy governance while minimizing the threat to domestic interests from international pressure on the climate change issue. This demonstrates the acute linkages between the domestic and international spheres that are intertwined in policymaking within these sensitive areas.

${ }^{54}$ Behrendt, "Beyond Santiago," 77.

55 "Kuwait Ranked More Corrupt," Kuwait Times, September 26, 2009.

${ }^{56}$ Cohen, "Sovereign Wealth Funds," 726.

57 Personal interviews, Abu Dhabi and Dubai, October 2009.

${ }^{58}$ Held, "Multilateralism and Global Governance," 202.

${ }_{59}$ Personal interview, Dubai, November 2009. 
GCC states occupy the top four global rankings in carbon dioxide emissions per capita, with Qatar's figure being more than double that of the UAE, which comes in at second place, and over three times that of the United States. ${ }^{60} \mathrm{~W}$ ith the notable exception of Oman, they have also developed a reputation for obstructionist tactics at successive rounds of climate change negotiations by focusing on what they decry as negative economic implications of a climate-changed world, rather than focusing on the environmental impacts of climate change itself. ${ }^{61}$ The enduring dominance of this approach was clearly demonstrated in comments made at an OPEC conference in March 2009 by Mohammed Al-Sabban, head of the Saudi delegation to the United Nations Framework Convention on Climate Change (UNFCCC). $\mathrm{He}$ warned that strict global proposals to mitigate climate change by cutting carbon emissions and curbing oil dependence represented a "very serious [threat] for oil producing countries and in particular Gulf producing countries," which "stand to lose out to such policies that are biased against oil producers." ${ }^{2}$ When scientists in the United Kingdom were accused of manipulating data to support their evidence for global warming, Al-Sabban seized on the revelation to cast doubt on the broader validity of climate science, arguing that "the size of [economic] sacrifices must be built on a secure foundation of information, which we found now is not true." ${ }^{63}$ Low public awareness of adaptation and mitigation measures is underpinned by political and institutional policies that support the unsustainable and environmentally destructive use of resources. ${ }^{64}$

It is against this backdrop that the Gulf states have made considerable efforts to become world leaders in renewable and alternative energy. Abu Dhabi campaigned hard to host the headquarters of the International Renewable Energy Agency at its flagship carbon-neutral Masdar City. ${ }^{65}$ The Masdar Initiative also encompasses the annual World Future Energy Summit, which launched in 2008, and the Masdar Institute of Science and Technology, which opened in September 2009. Together, they provide a world-leading platform for cutting-edge research into renewable and sustainable energy. They have also enabled Abu Dhabi to brand itself, somewhat improbably in light of its ecological footprint, as a global leader in the field. ${ }^{66}$ However, Abu Dhabi is not alone in seizing the initiative; in Saudi

\footnotetext{
${ }^{60}$ Mohamed A. Raouf, "Climate Change Threats, Opportunities, and the GCC Countries," (Policy Brief 12, Middle East Policy Institute, Washington DC, 2008), 15.

${ }^{61}$ Joanna Depledge, "Striving for No: Saudi Arabia in the Climate Change Regime," Global Environmental Politics 8, no. 4 (2008): 20.

${ }^{62}$ "Climate Action Plan to Harm Gulf Economies: Saudi Official," Saudi Gazette, March 20, 2009.

${ }_{63}$ Wael Mahdi, "Saudis Say Trust in Climate Science 'Shaken," The National, December 8, 2009.

${ }^{64}$ Andy Spiess, "Developing Adaptive Capacity for Responding to Environmental Change in the Arab Gulf States:Uncertainties to Linking Ecosystem Conservation, Sustainable Development and Society in Authoritarian Rentier Economies," Global and Planetary Change 64 (2008): 245.

65 "Abu Dhabi Home for World Energy Body."

${ }^{66}$ Telephone interview, Dubai, September 2009.
} 
Arabia the $\$ 10 \mathrm{bn}$-endowed King Abdullah University of Science and Technology, which also began operations in September 2009, includes a dedicated research track examining resources, energy, and environment issues with a particular emphasis on clean combustion technologies, as well as solar and alternative energy science. ${ }^{67}$ Meanwhile, in Qatar, the Al-Shaheen Oilfield Gas Recovery and Utilisation Project became, in May 2007, the first registered Clean Development Mechanism (CDM) project in the Gulf, and other CDM initiatives are currently underway in the renewable energy, waste, cement, and aluminum smelting sectors. ${ }^{68}$

Multiple and interlinking factors feed into these two ostensibly contradictory policy approaches at the domestic, regional, and global levels. The political economy of these oil monarchies renders them vulnerable to any shifts in demand for, or perceptions toward, fossil fuels. In a climate-stressed world where alternative and renewable sources of energy assume greater importance it is therefore in their interest to take proactive steps to shape the regulatory forms of global energy governance that emerge. ${ }^{69}$ Tied to this is a form of brand recognition that constitutes an additional layer of these small states' strategies for survival by embedding themselves as important actors in the international system. ${ }^{70}$ It also reflects an intense intraregional competitive pressure driving individual states to carve out separate niches that both outflank neighboring states and attract the foreign direct investment and international prestige that puts them on the map. ${ }^{71}$

Two examples demonstrate these factors at work. In February 2009, Qatar hosted the fourth Global Conference of the Extractive Industries Transparency Initiative (EITI), entitled "Establishing Resource Transparency," despite being neither a compliant nor a candidate country nor even a supporter that has declared its intent to implement the EITI. ${ }^{72}$ Association with the event plays into the Qatari projection of a global image that distinguishes it from the research initiatives being launched in Abu Dhabi and Saudi Arabia and increases Qatar's profile in this now crowded regional arena. Meanwhile, the United Arab Emirates has cooperated intensively with the International Atomic Energy Agency to ensure that its civil nuclear energy plans meet the highest standards of transparency, safeguarding, and monitoring in order to gain the support of the international community, especially the United States. ${ }^{73}$ US Congressional approval for the nuclear cooperation deal

${ }^{67}$ King Abdullah University of Science and Technology, accessed November 15, 2009, http://www.kaust.edu.sa/.

${ }^{68}$ Raouf, "Climate Change," 7.

${ }^{69}$ Goldthau and Witte, "Back to the Future," 383.

${ }^{70}$ J. E. Peterson, "Qatar and the World: Branding for a Micro-State," Middle East Journal 60, no. 4 (2006): 733.

${ }^{71}$ Telephone interview, Dubai, September 2009.

${ }^{72}$ Extractive Industries Transparency Initiative, “The 4th EITI Global Conference," accessed November 15, 2009, http://eiti.org/DohaConference.

${ }^{73}$ Ian Jackson, "Nuclear Energy and Proliferation Risks: Myths and Realities in the Persian Gulf," International Affairs 85, no. 6 (2009): 1157. 
offered by the outgoing Bush administration in January 2009 sent a powerful signal of geopolitical support for the UAE as a stable actor implementing nuclear energy in a responsible manner that addresses proliferation concerns and forms a model for other Middle Eastern states seeking nuclear energy capabilities. ${ }^{74}$

The Gulf states' emergence as active participants in framing new structures of governance in areas of geo-political and geo-economic importance to them is a significant factor in the reshaping of global institutions and governance. It simultaneously raises the international profile of the Arabian oil monarchies and enhances their stake in the efficacy of the global order. This involves the creation of new linkages that are shifting the international relations of the GCC states in subtle yet profound ways. Qatar's role in hosting and transforming the Gas Exporting Countries' Forum into an intergovernmental organization comprising the world's leading (and non-Western) gas producers is a prime example of the Gulf states' projection of newly-acquired confidence and autonomy in the international arena. ${ }^{75}$ There is, nonetheless, a paradoxical divergence between the Gulf states' expanding global role and the ongoing limited awareness of a global politics in the region, which the following sections address.

\section{Globalization and the Creation of a Global Politics}

This and the concluding section contextualize the changing engagement strategies of the Gulf states in the broader processes of globalization, the creation of a global politics, and the moves toward reformulating global governance. They examine Gulf perspectives on these issues and explore some of the implications for greater regional awareness of the nature of the global processes, as well as for the future trends of global governance itself. It proceeds from the argument that for all the breadth and depth of Gulf states' enhanced engagement on the global level, substantive identification with the notion of a global polity or global governance is still lacking. This is a characteristic common to many post-colonial and developing-world polities, in which state-centric visions of international organization predominate over any ideational attachment to more normative concepts of global governance. Thus, the Gulf states prioritize economic globalization while resisting its political and cultural dimensions. Furthermore, they focus on the practical implications of global engagement in order to shape the governance of globalizing processes.

Beginning in the post-WWII era but accelerating rapidly in the 1990s, the idea of political community was re-conceptualized into a distinctive form of global politics to account for the intensity and extensity of global interconnections and states'

\footnotetext{
74 Doug Palmer, "US-UAE Nuclear Deal to Take Effect Soon - State Dept," Reuters, October 22, 2009.

75 "Doha Gears up to Host Gas Exporting Countries' Forum," The Peninsula, June 29, 2009.
} 
engagement within transnational frameworks and issues. ${ }^{76} \mathrm{~A}$ multi-dimensional and polycentric system of governance also developed to govern the globalizing processes, combining sub-state and supra-state agencies alongside the national and inter-state frameworks of governance. ${ }^{77}$ These processes of globalization and global politics are closely intertwined with the rise of global civil society operating within and across national boundaries and developing new techniques of civic engagement with the globalizing world..$^{78}$

Although Western literature on the concept of global governance is itself far from monolithic, it nevertheless ascribes value to certain normative debates about the nature of trans-national democracy and global social justice. These are not necessarily uncontested in much non-Western discourse which instead puts forward its own set of views of legitimacy and authority. ${ }^{79}$ Colored by their experiences with foreign intervention and colonial control, Chinese and Indian discourses exhibit an underlying skepticism of global governance as an intrusion into their sovereign leadership. ${ }^{80}$ As such, an effective, non-Western-led form of governance of globalization is more likely to occur through inter-state cooperation and transnational networks. ${ }^{81}$

Within the GCC, similar filters exist, although their potency is not uniform across the six member states. Policymakers and academics in Kuwait, for example, exhibit a markedly greater openness to being "firmly part of the global village." In part, this reflects Kuwait's changing relationship with the West. During European colonialism, Kuwait's rulers played Great Powers against each other to maximize their domestic maneuverability in the early twentieth-century. ${ }^{82}$ Greater relative openness is also a powerful legacy of Kuwait's experience with Iraqi occupation in 1990 and the Western role in liberating the country in 1991, although this is undercut somewhat by the recurring political constraints in Kuwait that hold back its domestic, regional, and international projects. ${ }^{83}$ In contrast, Bahrain was the seat of Anglo-Indian and (after 1947) British control in the Gulf until 1971, and attitudes

${ }_{76}$ David Held and Anthony G. McGrew, introduction to Governing Globalization: Power, Authority and Global Governance (Cambridge: Polity Press, 2002), 5.

77 Jan Aart Scholte, "Civil Society and Democratically Accountable Global Governance," in Global Governance and Public Accountability, ed. David Held and Mathias Koenig-Archibugi (Oxford: Blackwell and Wiley, 2005), 90.

${ }^{78}$ Mary Kaldor, Helmut Anheier, and Marlies Glasius, “Global Civil Society in an Era of Regressive Globalisation,” in Global Civil Society 2003, ed. Kaldor, Anheier, and Glasius (Oxford: Oxford University Press, 2003), 3.

79 David Held, "Democracy: the Nation-State and the Global System," in Modernity: Critical Concepts, vol. 4, After Modernity, ed. Malcolm Waters (New York: Routledge, 1999), 411.

${ }^{80}$ Lai-Ha Chan, Pak K. Lee, and Gerald Chan, "Rethinking Global Governance: a China Model in the Making?" Contemporary Politics 14, no. 1 (2008): 7; Teresita C. Schaffer, "The United States, India and Global Governance: Can They Work Together?” The Washington Quarterly 32, no. 3 (2009): 72.

${ }^{81}$ Robert O. Keohane, "Governance in a Partially Globalized World," in Governing Globalization: Power, Authority and Global Governance, ed. David Held and Anthony G. McGrew (Cambridge: Polity Press, 2002), 325.

82 B. J. Slot, Mubarak Al-Sabab: Founder of Modern Kuwait, 1896-1915 (London: Arabian Publishing Limited, 2005), 295-6.

${ }^{83}$ Personal interviews, Kuwait, October 2009 and March 2010. 
toward global politics and global governance are inevitably colored by this legacy of foreign intrusion into state sovereignty. ${ }^{84}$ Such ambivalence about global issues is a common thread that links the Gulf, and the wider Arab world, to other post-colonial regions. It manifests itself in a tendency to perceive moves toward global politics as part of a broader Western, particularly American, hegemonic project, and this negatively informs perceptions of global civil society organizations as well. ${ }^{85}$

A degree of suspicion of global politics is thus rooted in the relationship of the Arab and other post-colonial worlds with what are considered to be the hegemonic injustices of the international system. This view is widespread in the Gulf states and is a regular feature of both popular and political discourse in the region. It ranges from outspoken claims from Islamist scholars such as Qatar-based cleric Yusuf alQaradawi that globalization "from the beginning has been linked to the expansion of the American model" to a more widespread perception that globalization is aimed at reproducing the models of Western hegemony in a different albeit more benign format than colonialism did. ${ }^{86}$ There is also a separation of economic globalization, in which the Gulf states are much more willing to participate, from political and cultural globalization, which they resist as an ideational threat to national security and interests. ${ }^{87}$ It was in this vein that the Governor of Makkah Province Prince Khaled al-Faisal bin Abdul Aziz al-Saud warned, in April 2009, that the Saudi youth "finds himself caught between two forms of extremism" - the Takferi and Westernization trends - in which "each ideology tries to take him to its side leaving him confused and in need of knowing who he is and what his culture stands for." 88

All of these factors contribute to a low level of awareness and acceptance of the concept of a global political community. This might seem paradoxical on a superficial level in light of the GCC states' increasingly visible emergence as global actors. Nevertheless, as the previous sections make clear, low regional awareness of global political culture does not imply that the six Gulf states are marginalized in international institutions and forums, nor that they are passive observers of the changing global order. Intellectual skepticism about normative concepts of globalization and global governance certainly does not distance the GCC states from acting as global players. Rather, it demonstrates how the Gulf states form part of a broader typology of non-Western discourses on global issues that differ substantively

\footnotetext{
${ }^{84}$ Personal interviews, Bahrain, October 2009.

${ }^{85}$ Mohamed E-Sayed Said, "Global Civil Society: An Arab Perspective," in Global Civil Society Yearbook 2004/5, ed. Helmut Anheier, Marlies Glasius, and Mary Kaldor (London: Sage, 2004), 60; Marc Lynch, "Globalization and Arab Security," in Globalization and National Security, ed. Jonathan Kirshner (New York: Routledge, 2006), 188.

86 al-Qaradawi quote in Lynch, "Globalization and Arab Security," 189; Personal interview, Kuwait, October 2009.

87 Personal interview, Dubai, November 2009.

88 Saeed Al-Serahi, "Khaled Stresses Consolidation of Saudi Moderation Policies," Saudi Gazette, March 18, 2009; "Saudi Arabia Committed to Moderate Policies," Khaleej Times, April 2, 2009.
} 
from the often-normative debates taking place in the West. This reflects the powerful legacy of colonialism in shaping the nature of the international system in the Middle East and how states and societies alike relate to it. ${ }^{89}$ Understanding this divergence contextualizes and enhances the analytical study of the Gulf states' perspectives on global engagement and the motivations and objectives that guide policymakers in their decision-making processes.

\section{Conclusion: Implications for Global Governance}

This final section addresses the implications of the global rebalancing of power for the existing and future layers of global and regional governance. It considers the embedding of certain global values like human rights and good governance as a significant move in the direction of a global consensus on these issues. Nevertheless, it also argues that the Gulf states now possess plausible alternative partnerships in Asia and Africa that do not necessarily prioritize further progress on these normative issues. For these reasons, the future of global governance is likely to be characterized by moves toward the creation of a more cooperative international environment and a new institutional architecture that reflects the diffuse centers of influence. This will need to be responsive to the rapidly-changing global framework while balancing the competing objectives of different stakeholders, including the emergence of multiple poles of gravity and new coalitions of states and inter-regional agreements.

The fragmentation of the international order and the emergence of a multipolar world means that the impact of global processes and values will vary according to regional and national conditions. ${ }^{90}$ Socio-political, economic, and cultural filters all play a role in shaping the particular environments within which norms and values are embedded. This is evident in the case of human rights advocacy, which has entered mainstream political and popular discourse over the past decade, in the Gulf as elsewhere throughout the Middle East. ${ }^{91}$ All of the GCC states have created official or semi-official human rights bodies while Bahrain (2006 and 2008), Qatar (2007), and Saudi Arabia (2009) have been elected to the United Nations Human Rights Commission. Meanwhile in December 2008, human rights organizations in the Gulf actively marked the $60^{\text {th }}$ anniversary of the Universal Declaration of Human Rights with a range of activities and public diplomacy outreach designed to spread awareness of the concept of human rights. These included the convening of the first Arab Conference on Human Rights in Doha and an announcement that the

\footnotetext{
89 Fred Halliday, The Middle East in International Relations: Power, Politics and Ideology (Cambridge: Cambridge University Press, 2005), 36.

90 Held, "Nation-State and the Global System," 411.

91 Said, "An Arab Perspective," 69.
} 
United Arab Emirates was to introduce human rights education in primary school curricula. ${ }^{92}$

Nevertheless, the GCC states lag far behind in the actual implementation of human rights instruments. Only Kuwait and Bahrain have ratified the International Covenant on Civil and Political Rights while Kuwait alone has ratified the International Covenant on Economic, Social and Cultural Rights. ${ }^{93}$ Officials in the GCC states regularly accuse Western organizations and activists of politicizing human rights reports and basing them on values unacceptable to "traditional value systems.” Thus, Dr Anwar Gargash, Minister of Foreign Affairs in the UAE, rejected twelve of the recommendations made by the United Nations Human Rights Council in its 2008 annual review, noting that "it is very difficult to take the value system of a certain society and superimpose it on another society." ${ }^{94}$ The sensitivities surrounding perceived Western-led pressure on human rights became clear in the collapse of the long-running negotiations for a free trade agreement between the GCC and the European Union. Talks collapsed in late-2008 owing to the EU's insistence upon imposing political conditions, including human rights clauses, in any final agreement. ${ }^{95}$ The Deputy Prime Minister of Qatar, Abdullah bin Hamad Al-Attiyah, criticized the "hidden agenda" that included "irrational issues that have nothing to do with free trade." He added, "Our experience with the discussions we've had with the EU, has been that on reaching the signing stage, the EU surprised us with issues that have nothing to do with free trade. ${ }^{96}$

In stark contrast to the stalled negotiations with the EU is the GCC's rapid progress in free trade negotiations with Asian partners, including India, Singapore, China, and the ASEAN bloc. Once again, these diverging pathways of negotiation demonstrate the shifting nexus of political and economic linkages that are repositioning the Gulf in the international system. Trade-focused agreements with Asian powers offer the GCC states a plausible range of alternative partnerships to the more interventionist European Union and United States. Particularly in the case of China, its pragmatic foreign policy with emphasis on non-intervention and state sovereignty is especially attractive to Saudi Arabia and the other Gulf states. ${ }^{97}$

\footnotetext{
92 "National Human Rights Commission Planned in UAE," Khaleej Times, December 5, 2008; "First Arab Human Rights Conference in Qatar," Kuwait Nerws Agency, December 5, 2008; "EU Praises Doha's Human Rights Efforts," Gulf Times, December 10, 2008.

${ }^{93}$ United Nations Development Programme, Arab Human Development Report 2009: Challenges to Human Security in Arab Countries (New York: United Nations Publications, 2009), 258.

${ }^{94}$ Preeti Kannan, "UAE Turns Down More UN Advice on Human Rights," Khaleej Times, March 13, 2009; The rejected recommendations included one from Finland that called on the UAE to ratify the International Covenant on Civil and Political Rights.

${ }_{95}$ Personal interview, Dubai, October 2009.

${ }^{96}$ Jaber Al Musallam, "Attiyah Calls For Timeframe to Conclude GCC-EU Trade Talks," The Peninsula, April $17,2009$.

${ }^{97}$ Ghafouri, "China's Policy in the Persian Gulf," 90.
} 
The differing experience of trade negotiations with the EU and those with Asian states raises the possibility of global realignments between compatible groups of states sharing a skeptic view of international criticism focusing on Western-centric norms. This has obvious implications for the future of normative concepts of global governance as blocs of developing nations coalesce in a loose and informal counterweight to Western-led discourse on notions of governance and what constitutes a global norm.

Similar dynamics are reworking the structural architecture of global governance as it emerges from the aftermath of the global economic and financial crisis. The most notable feature is the continuing relevance of the state in shaping the changes to the international system, and the strong likelihood that the strengthening linkages between developing countries will entrench still further the durability of the state system. The strongly state-centric approaches to global governance that characterize Chinese and Indian policymaking are shared by the majority of developing states, particularly post-colonial ones, including those in the GCC. Thus, the reformulation of the global institutional structure will likely resemble an international, rather than global, framework of governance. A greater emphasis on mechanisms such as regional states-systems will assist developing countries to more carefully control and negotiate the terms of their integration into the global economy. ${ }^{98}$

In addition, the policy responses of governments around the world to the financial crisis in 2008-2009 further highlighted the continuing relevance of the state in the contemporary international system. The massive bailouts of financial companies, and others including the US automobile industry, through government economic stimulus packages fundamentally shifted the parameters of the debate over the proper role of the state away from the principles espoused in the Washington Consensus. Somewhat ironically, the new paradigm more closely resembles statesponsored capitalism models than it does the minimal state models associated with pro-market and neo-liberal proponents. State-sponsored capitalism models posit state intervention as a critical and primary engine for growth, and the approach has long been followed in the East Asian and Gulf states. ${ }^{99}$

This neither diminishes the complexity of global issues nor lessens the urgency of developing mechanisms for addressing them. The internationalization of the global financial and economic crisis underscored the intensity and extensity of global interconnections and the necessity for coordinated and collaborative responses. ${ }^{100}$ Meanwhile, the fractious proceedings at the 2009 United Nations

\footnotetext{
${ }_{98}$ Andrew Hurrell, "One World? Many Worlds? The Place of Regions in the Study of International Society," International Affairs 83, no. 1 (2007): 131.

${ }_{99}$ Tim Niblock and Monica Malik, The Political Economy of Saudi Arabia (London: Routledge, 2007$), 8$.

${ }^{100}$ David Held, "Global Challenges: Accountability and Effectiveness," Open Democracy, accessed October 10, 2010,http://www.opendemocracy.net/article/global_challenges_accountability_and_effectiveness.
} 
Climate Change Conference in Copenhagen demonstrated the inadequacy and unsuitability of current frameworks of governance to deal with complex global processes and issues such as climate change. ${ }^{101}$ The challenge, both for emerging global actors, among them the Gulf states, and existing world powers, is first to identify appropriate problem-solving capabilities at the regional and global levels and then to formulate workable mechanisms for implementing them. In order to be successful, any solutions need to address the structural limitations of the post-1945 settlement in order to reflect the changing balance of global political and economic power and consider the practical implications of the rise in state-centric approaches for the evolution of global governance.

Consequently, the broadening and deepening of bilateral and multilateral ties between the Gulf states and their African and Asian partners, in particular, offers alternative models of economic and political development and pathways to global engagement. This also has implications for moves toward regionalism and the direction of international organizations such as the GCC itself. The evidence of recent fractures within the GCC suggests that the Gulf states are prioritizing internationalization over continued regionalization. The monetary union dispute which prompted the UAE to leave the single currency project in 2009 was rapidly followed by naval skirmishes between Qatar and Bahrain, and Saudi Arabia and the UAE, which also share unresolved boundary tensions. Perhaps emblematically, the bilateral nuclear cooperation deal between the UAE and the United States came at the expense of the regional plan announced at the 2006 GCC Heads of State Summit in Riyadh for a joint nuclear energy program. Moreover, individual GCC states are engaged in intense competition for market share and position in fields ranging from global aviation to logistical and financial hubs to higher education. ${ }^{102}$ This is by no means a phenomenon unique to the GCC, as made clear by continuing preferences for bilateral approaches to foreign policymaking and deep divisions within the EU over the handling of the Greek financial crisis. Patterns of global engagement and the pursuit of internationalization are thus reconfiguring the position of individual states within the global order and injecting new dynamics into intra-regional and international relations.

This diversification of the GCC states' geo-political and geo-economic interests is a profoundly significant juncture in the processes of internationalizing the Gulf and repositioning it within the changing global order. It requires a new approach to research and policy briefing, both within the Gulf states and the wider international arena, that takes the new paradigm as the starting-point for further analysis of the

\footnotetext{
${ }^{101}$ John Vidal, "Rich and Poor Countries Blame Each Other for Failure of Copenhagen Deal," The Guardian, December 19, 2009.

${ }^{102}$ For an in-depth assessment of Gulf states' competitiveness in the global aviation industry, see "Aviation in the Gulf: Rulers of the New Silk Road," special report, The Economist, June 3-9, 2010.
} 
Gulf states' changing engagement strategies within the global community. These include additional research on issues such as changes to trade patterns, financial flows and foreign direct investment, the convergence or otherwise of local and global conversations on issues such as climate change and energy sustainability, and implications for regional and global security structures and strategic partnerships. Moving to a macro-analytical level, future work might build upon the contextualization of the Gulf's repositioning within the broader transformation of East-West relations to consider the impact of these changes on existing and future security frameworks, the compatibility or otherwise of regionalization and internationalization, as well as on the prospects for multilateral decision-making and the evolution of the international order in the years and decades to come. 


\section{BIBLIOGRAPHY}

“Abu Dhabi Home for World Energy Body." The Peninsula, June 30, 2009.

Al Musallam, Jaber. "Attiyah Calls For Timeframe to Conclude GCC-EU Trade Talks.” The Peninsula, April 17, 2009.

Al-Serahi, Saeed. "Khaled Stresses Consolidation of Saudi Moderation Policies." Saudi Gazette, March 18, 2009.

Baabood, Abdullah. "Dynamics and Determinants of the GCC States' Foreign Policy, with Special Reference to the EU." In Analyzing Middle Eastern Foreign Policies, edited by Gerd Nonneman, 145-73. London: Routledge, 2005.

Baabood, Abdullah, and Geoffrey Edwards. "Reinforcing Ambivalence: The Interaction of Gulf States and the European Union." European Foreign Affairs Review 12, no. 4 (2007): 537-54.

Behrendt, Sven. "Beyond Santiago: Status and Prospects." Central Banking 19, no. 4 (2009): 75-80.

Chan, Lai-Ha, Pak K. Lee, and Gerald Chan. "Rethinking Global Governance: a China Model in the Making?" Contemporary Politics 14, no. 1 (2008): 3-19.

"Climate Action Plan to Harm Gulf Economies: Saudi Official." Saudi Gazette, March 20, 2009.

Cody, Edward. "First French Military Base Opens in the Persian Gulf." The Washington Post, May 27, 2009.

Cohen, Benjamin J. "Sovereign Wealth Funds and National Security: The Great Tradeoff." International Affairs 85, no. 4 (2009): 713-31.

Davidson, Christopher M. "Persian Gulf - Pacific Asia Linkages in the $21^{\text {st }}$ Century: A Marriage of Convenience?” Working Paper 7, Kuwait Programme on Development, Governance, and Globalisation, London School of Economics, 2010.

Depledge, Joanna. "Striving for No: Saudi Arabia in the Climate Change Regime." Global Environmental Politics 8, no.4 (2008): 9-35.

“Doha Gears up to Host Gas Exporting Countries' Forum.” The Peninsula, June 29, 2009. 
Dupont, Alan, and Mark Thirlwell. "A New Era of Food Insecurity?” Survival 51, no. 3 (2009): 71-98.

"EU Praises Doha’s Human Rights Efforts." GulfTimes, December 10, 2008.

Extractive Industries Transparency Initiative. "The 4th EITI Global Conference." Accessed November 16, 2009. http://eiti.org/DohaConference.

"First Arab Human Rights Conference in Qatar." Kuwait Nerws Agency, December 5, 2008.

Ghafouri, Mahmoud. "China's Policy in the Persian Gulf." Middle East Policy 16, no. 2 (2009): 80-92.

Goldthau, Andreas, and Jan Martin Witte. "Back to the Future or Forward to the Past? Strengthening Markets and Rules for Effective Global Energy Governance." International Affairs 85, no. 2 (2009): 373-90.

"Gulf States and ASEAN Eye New Trade Bloc Based on Food, Oil." The Peninsula, July 1, 2009.

Habboush, Mahmoud. "Chinese Warships Make First Visit to Port Zayed.” The National, March 24, 2010.

Halliday, Fred. The Middle East in International Relations: Power, Politics and Ideology. Cambridge: Cambridge University Press, 2005.

Held, David. "Democracy: the Nation-State and the Global System." In Modernity: Critical Concepts, vol. 4, After Modernity, edited by Malcolm Waters, 411-45. New York: Routledge, 1999.

. "Global Challenges: Accountability and Effectiveness." Open Democracy. Accessed October 10, 2010. http://www.opendemocracy.net/article/global_ challenges_accountability_and_effectiveness.

. "Multilateralism and Global Governance: Accountability and Effectiveness." In Progressive Foreign Policy: New Directions for the UK, edited by David Held and David Mepham, 191-212. Cambridge: Polity Press, 2007.

Held, David, and Anthony G. McGrew. Introduction to Governing Globalization: Power, Authority and Global Governance, edited by David Held and Anthony G. McGrew, 1-21. Cambridge: Polity Press, 2002. 
Hurrell, Andrew. "One World? Many Worlds? The Place of Regions in the Study of International Society." International Affairs 83, no. 1 (2007): 127-46.

Hussein, Ourouba. "Qatari PM Stresses Rule of Law to Face Challenges." Gulf Times, May 31, 2009.

Hvidt,Martin. “The Dubai Model: An Outline of Key Development-Process Elements in Dubai." International Journal of Middle East Studies 41, no. 3 (2009): 397418.

Jackson, Ian. "Nuclear Energy and Proliferation Risks: Myths and Realities in the Persian Gulf." International Affairs 85, no. 6 (2009): 1157-72.

Kaldor Mary, Helmut Anheier, and Marlies Glasius. "Global Civil Society in an Era of Regressive Globalisation.” In Global Civil Society 2003, edited by Kaldor, Anheier and Glasius, 3-33. Oxford: Oxford University Press, 2003.

Kannan, Preeti. "UAE Turns Down More UN Advice on Human Rights." Khaleej Times, March 13, 2009.

Keohane, Robert O. "Governance in a Partially Globalized World.” In Governing Globalization: Power, Authority and Global Governance, edited by David Held and Anthony G. McGrew, 325-47. Cambridge: Polity Press, 2002.

Khan, Ghanzafar Ali. "China to Boost Relations with GCC: President Hu." Arab News, February 12, 2009.

King Abdullah University of Science and Technology. Accessed November 15, 2009. http://www.kaust.edu.sa/

Kostiner, Joseph. Middle East Monarchies: The Challenge of Modernity. Boulder: Lynne Rienner, 2000.

"Kuwait and China Sign Energy, Other Pacts." Saudi Gazette, May 11, 2009.

“Kuwait Ranked More Corrupt.” Kuwait Times, September 26, 2009.

Lynch, Marc. "Globalization and Arab Security." In Globalization and National Security, edited by Jonathan Kirshner, 171-200. New York: Routledge, 2006.

Mahdi, Mazen. "US to Double Size of Bahrain Naval Base." The National, May 27, 2010. 
Mahdi, Wael. "Saudis Say Trust in Climate Science 'Shaken.” The National, December 8, 2009.

Mathew, Ramesh. “Indian PM Woos Qatar Investment.” GulfTimes, November 11, 2008.

. "Qatar and India Agree to Expand Security Ties." Gulf Times, November 10, 2008.

Mouawad, Jad. "China's Growth Shifts the Geopolitics of Oil.” The New York Times, March 19, 2010.

"National Human Rights Commission Planned in UAE." Khaleej Times, December 5, 2008.

Niblock, Tim and Monica Malik. The Political Economy of Saudi Arabia. London: Routledge, 2007.

Nonneman, Gerd."Determinants and Patterns of Saudi Foreign Policy: 'Omnibalancing' and 'Relative Autonomy' in Multiple Environments." In Saudi Arabia in the Balance: Political Economy, Society, Foreign Affairs, edited by Paul Aarts and Gerd Nonneman. London: Hurst, 2005.315-51.

Palmer, Doug. "US-UAE Nuclear Deal to Take Effect Soon - State Dept.” Reuters, October 22, 2009.

Peter, Sajeev K. “Kuwait, India Sign Three Agreements.” Kuwait Times, April 8, 2009.

Peterson, J. E. "Qatar and the World: Branding for a Micro-State." Middle East Journal 60, no. 4 (2006): 732-48.

Pradhan, Samir Ranjan. "GCC-Asia Relations: Intensifying Cooperation Beyond Mutual Interdependence." In Gulf Yearbook 2008-2009, edited by Abdulaziz Sager, 157-73. Dubai: Gulf Research Centre, 2009.

"Qatar to Become Largest LNG Supplier to China." The Peninsula, September 2, 2009.

"Qatari Emir Warns of Another Iraq if Sudan Sinks into Chaos." GulfTimes, March $31,2009$.

Raouf, Mohamed A. "Climate Change Threats, Opportunities, and the GCC Countries.” Policy Brief 12, Middle East Institute, Washington DC, 2008. 
"Riyadh is the Gulf's New Financial Centre." Middle East Economic Digest, June 26, 2009.

Romani, Vincent. "The Politics of Higher Education in the Middle East: Problems and Prospects." Middle East Brief 36, Crown Center for Middle East Studies, Brandeis University, 2009.

Sager, Abdulaziz O. “The G20 Meeting and Gulf Interests." Gulf Research Centre. Accessed March 23, 2009, http://www.grc.ae.

Said, Mohamed El-Sayed. "Global Civil Society: An Arab Perspective.” In Global Civil Society Yearbook 2004/5, edited by Helmut Anheier, Marlies Glasius and Mary Kaldor, 60-73. London: Sage, 2004.

Samba Financial Group. “Tracking GCC Foreign Investments: How the Strategies are Changing with Markets in Turmoil." Samba Report Series, Samba Financial Group, Riyadh, December 2008.

“Saudi Arabia Committed to Moderate Policies.” Khaleej Times, April 2, 2009.

"Saudi Arabia Not Mulling More Cash for IMF: Minister." Reuters, November 16, 2008.

"Saudi Says IMF Reforms Should Not Be at Its Expense." The Peninsula, September 5, 2009.

"Saudis Setting up Fund to Buy Agricultural Land Abroad." GulfTimes, August 26, 2008.

“Saudi to Keep June Oil Supply Steady to Asia." Reuters, May 12, 2009.

Schaffer, Teresita C. "The United States, India and Global Governance: Can They Work Together?” The Washington Quarterly 32, no. 3 (2009): 71-87.

Scholte, Jan Aart. "Civil Society and Democratically Accountable Global Governance." In Global Governance and Public Accountability, edited by David Held and Mathias Koenig-Archibugi, 87-109.Oxford: Blackwell and Wiley, 2005.

Slot, B. J. Mubarak Al-Sabab: Founder of Modern Kuwait, 1896-1915. London: Arabian Publishing Limited, 2005.

Smith, Mark A. "Russia and the Persian Gulf: The Deepening of Moscow's Middle East Policy.” Middle East Series Paper, Conflict Studies Research Centre, Defence Academy of the United Kingdom, 2007. 
Spiess, Andy. "Developing Adaptive Capacity for Responding to Environmental Change in the Arab Gulf States: Uncertainties to Linking Ecosystem Conservation, Sustainable Development and Society in Authoritarian Rentier Economies." Global and Planetary Change 64 (2008): 244-52.

Ulrichsen, Kristian. "Dubai's Downfall Exposes the Political Ties that Bind in a Tangled Web.” Daily Telegraph, December 2, 2009.

United Nations Development Programme, Regional Bureau for Arab States. Arab Human Development Report 2009: Challenges to Human Security in Arab Countries. New York: United Nations Publications, 2009.

“US Praises Gulf Investments to Push Growth." Agence France-Presse, July 14, 2009.

“US Seeks \$300bn from Gulf States to Tackle Turmoil." Agence France-Presse, November 21, 2008.

Vidal, John. "Rich and Poor Countries Blame Each Other for Failure of Copenhagen Deal." The Guardian, December 19, 2009.

Wilson, Rodney. "Economic Governance and Reform in Saudi Arabia." In Reform in the Middle East Oil Monarchies, edited by Anoushiravan Ehteshami and Steven M. Wright, 132-52. Reading: Ithaca Press, 2008.

Woertz, Eckart. “The Gulf Economies in 2008.” In GulfYearbook 2008-2009, edited by Abdulaziz Sager, 233-54. Dubai: Gulf Research Centre, 2009.

Worth, Robert F. "Qatar, Playing All Sides, Is a Non-Stop Mediator." The New York Times, July 9, 2008.

Yetiv, Steve A., and Chunlong Lu. "China, Global Energy and the Middle East." Middle East Journal 61, no. 2 (2007): 199-218.

Youngs, Richard. "Impasse in Euro-Gulf Relations."Working Paper 80, Fundación para las Relaciones Internacionales y el Diálogo Exterior, Madrid, 2009.

Zhihong, Wan. "Sinopec's Fujian Plant up, Running." China Daily, November 12, 2009. 


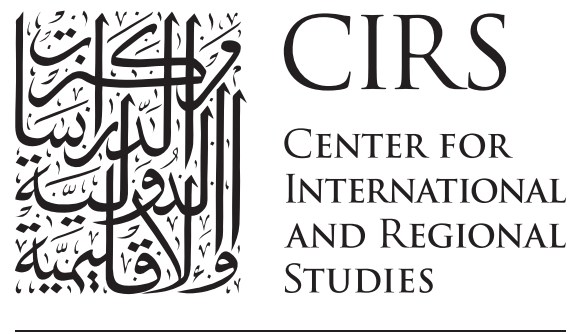

\section{GEORGETOWN UNIVERSITY} SCHOOL OF FOREIGN SERVICE IN QATAR

Center for International and Regional Studies Georgetown University School of Foreign Service in Qatar P.O. Box 23689

Doha, Qatar

http://cirs.georgetown.edu

Tel +97444578400

Fax +974 44578401 


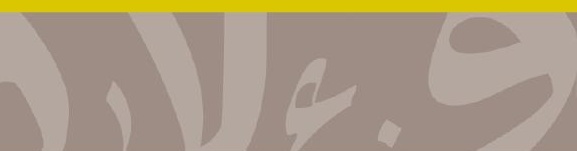

